\title{
Benevolent Benedictines? Vulnerable missions and Aboriginal policy in the time of A.O. Neville
}

Elicia Taylor

[Eliza] must understand distinctly that when she reaches Perth she is under my control, and must do as she is told. ${ }^{1}$

Subsequently Eliza was brought to me by Policewoman Dugdale, and she [Eliza] claimed that she was the daughter of a half-caste by a white father, and was not therefore subject to the provisions of the Aborigines Act in regard to her movements and our desire to send her back to the Mission. ${ }^{2}$

In August 1932, a young woman's escape from a Perth boarding house raised considerable anxiety within the Western Australian Aborigines Department. As a resident of the Benedictine mission known as New Norcia, Eliza had been staying at a Perth boarding house while receiving medical treatment. However, upon learning that her treatment was to be terminated and that she would be returning to New Norcia, Eliza rebelled. Not only did she refuse to submit to mission authorities, Eliza also challenged the Aborigines Department's authority to control her welfare.

At first glance, this incident suggests a level of collusion between state and church in managing the Indigenous population in Western Australia at the time. However, a closer examination of interactions between the Aborigines Department and New Norcia authorities reveals a much more complicated relationship. From his earliest days as Superior of New Norcia, Abbot Anselm Catalan challenged what he believed to be an anti-Catholic bias within the Aborigines Department. The Abbot's

1 Neville to Catalan, 21 May 1931, Archives of the Benedictine Community of New Norcia (hereafter ABCNN) 05120 .

2 Bray to Catalan, 25 August 1932, ABCNN 05120. 
suspicions certainly fuelled significant state-mission tension. Examining his interactions with the Chief Protector of Aborigines, A.O. Neville, facilitates a more nuanced understanding of the social and political conditions affecting missions, and the consequences for missionaries' treatment of Indigenous populations.

This article unpacks points of conflict and compliance between Catalan and Neville as played out in individual cases where Aboriginal people negotiated with these authorities. The Benedictine missionaries' sense of vulnerability is an overriding consideration within this study as we learn of their battles to maintain a Catholic presence amongst the local Indigenous population, while at the same time dealing with the state's increasingly severe restrictions on Aboriginal lives and mission operations. Within this context, Catalan's behaviour treads an unsteady path between resistance and accommodation in his relationship with the Aborigines Department.

This study is based upon the rich archival records of the Benedictine Community of New Norcia. Correspondence between Abbot Catalan and the Aborigines Department held within this archive provides important insights into the nature of the relationship, and its consequences for local Aboriginal communities. Christine Choo and Katharine Massam have also utilised the New Norcia archives in their important works addressing missionary relationships with the Aboriginal community, although such works have not focused in detail on this specific statemission relationship. ${ }^{3}$ The insights gained from studying New Norcia's relationship with the Aborigines Department contribute to our understanding of the complexities and nuances within the Aboriginal experience, and highlight the need to avoid oversimplifying the depiction of missions as either complicit and compliant or resistant and 'rebellious' towards the Aboriginal policies pursued by the state. These dichotomies are not particularly helpful in evaluating the tangled nature of some state-mission relationships.

Within this study we find surprising acts of resistance by Benedictine priests towards state interference, as well as rare and tantalising glimpses of Aboriginal reactions to such behaviour. However, as is so often the case when trying to uncover Indigenous experiences from the archives, their perspectives are mostly absent or obscured, requiring careful reading and interpretation of documents against the grain. Wherever possible, examples of Aboriginal voice that I encountered within the records have been brought into the foreground of this article. In the course of my research, and realising the sensitive and personal nature of the records I would be examining, I contacted the New Norcia Aboriginal Corporation, an organisation founded in the 1990s to build and empower Aboriginal family support structures and foster community connections. ${ }^{4}$ Some members of this organisation are

3 Choo 2001; Massam 2015.

4 New Norcia Benedictine Community, 'Support from the New Norcia Aboriginal Corporation', www.new norcia.wa.edu.au/special-events/2014-salvado-bicentenary-year/nnac (accessed 30 August 2017). 
descendants of former residents of New Norcia. Having received the organisation's consent for this research project, I hope that I have done justice to the information that can be gleaned from the archival record. As a condition of accessing the New Norcia archives, I agreed to change the names of all Aboriginal people referred to in this article.

\section{'Civilising' missionaries}

Existing scholarship on missionaries' 'civilising' endeavours has contributed enormously to our understanding of the variety and complexity of issues arising from missionary involvement in colonisation. Within the Australian context, historians have tempered their references to the benevolence of missionary activities by recognising that many of the individuals assigned to missionary work were either physically or mentally unsuited for the challenging conditions they encountered, and that mission organisations often struggled to secure adequate support from the state. ${ }^{5}$ By magnifying specific state-missionary relationships, historians have developed a deeper understanding of how state policies were sometimes influenced by including missionaries in the 'civilising' process. For example, despite significant tensions identified by both Choo and Noel Loos in their studies of mission organisations in Western Australia and Queensland, these historians point to a symbiotic relationship in which missions were dependent upon state support for their existence, and state bureaucrats were reliant on mission compliance with policies related to Aboriginal child removal, institutionalisation and assimilation. ${ }^{6}$

In her recent biography of Mount Margaret Mission teacher and activist Mary Bennett, Alison Holland explains how missions could also find their supportive state relationship rapidly deteriorating due to outspoken missionaries who resisted government policy. Holland specifically refers to the Mount Margaret missionaries' increasingly acrimonious relationship with A.O. Neville, and their distinct sense of vulnerability as they opposed restrictive government policies while also struggling to maintain state support for their operations. ${ }^{7}$ While Holland accounts for a gradually deteriorating state-mission relationship, the constantly precarious status assumed by missionaries within colonial regimes also warrants consideration. In his theoretical examination of competing models of colonialism in nineteenth-century South Africa, John Comaroff explains that British missionaries were regarded as both a 'dominated faction of the dominant class', and 'friends and protectors of the natives', effectively setting them at odds with the agenda of the dominant colonial ruling classes. ${ }^{8}$ Comaroff's conception of the missionaries' conflicted relationship

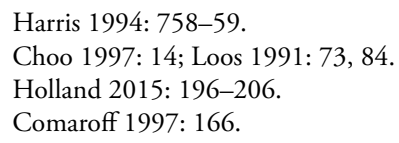


to colonial governing bodies complements Holland's suggestion of missionary vulnerability, with both ideas providing useful frameworks for considering the relationship between Benedictine missionaries and the state. In the discussion that follows, we can see that the vulnerability of the mission significantly impacted upon its capacity or will to resist state pressure.

\section{A complicated relationship}

At the heart of this study are the complex interactions between Western Australian Chief Protector of Aborigines Auber Octavius (A.O.) Neville and New Norcia's Superior, Abbot Catalan, both of whom shared varying levels of responsibility for New Norcia's Aboriginal community. Neville had been appointed to the role of Chief Protector of Aborigines in 1915 without any prior experience of issues affecting Indigenous communities. According to his biographer Pat Jacobs, Neville was an extremely capable administrator within the Department of Immigration and Tourism to the extent that his skills were highly sought after by the Aborigines Department. While he eventually agreed to the transfer, Neville had been hesitant to leave his position in Immigration and Tourism to take on the much lower status and budget attached to the Aborigines Department. ${ }^{9}$

Abbot Anselm Catalan had also been reluctant to accept his position as Superior of New Norcia. He had been educated at the Benedictine Abbey of Montserrat in Catalonia, Spain, and ordained in $1902 .{ }^{10}$ After spending eight years at St Bede's College, Manila, and as procurator of the Benedictine missions in the Philippines, Catalan was appointed as an Abbot Visitor to New Norcia in 1914 upon the death of Abbot Torres, to oversee the election of Torres's successor. Catalan had intended to return and spend the rest of his life at Montserrat, but, to his consternation, he was formally elected Superior of New Norcia in 1916 where he remained for the next 35 years. ${ }^{11}$ Catalan continued his predecessor's focus on monastic and liturgical life while also revitalising the mission by stabilising and modernising its property and equipment. ${ }^{12}$

\footnotetext{
9 Jacobs 1990: 53-54.

10 Mulcahy 1993. The year in which Catalan was ordained is contested with Mulcahy suggesting 1902, while Hutchison asserts 1901. See Hutchison 1995: 85.

11 While the Australian Dictionary of Biography lists Catalan's commencement at New Norcia as 1915 (Mulcahy 1993), he was not officially elected as Superior until 1916; New Norcia Benedictine Community, 'The Story of New Norcia: The Monastic Town 1901-1950', www.newnorcia.wa.edu.au/heritage/history (accessed 1 August 2018); Hutchison 1995: 85.

12 Hutchison 1995: 86
} 


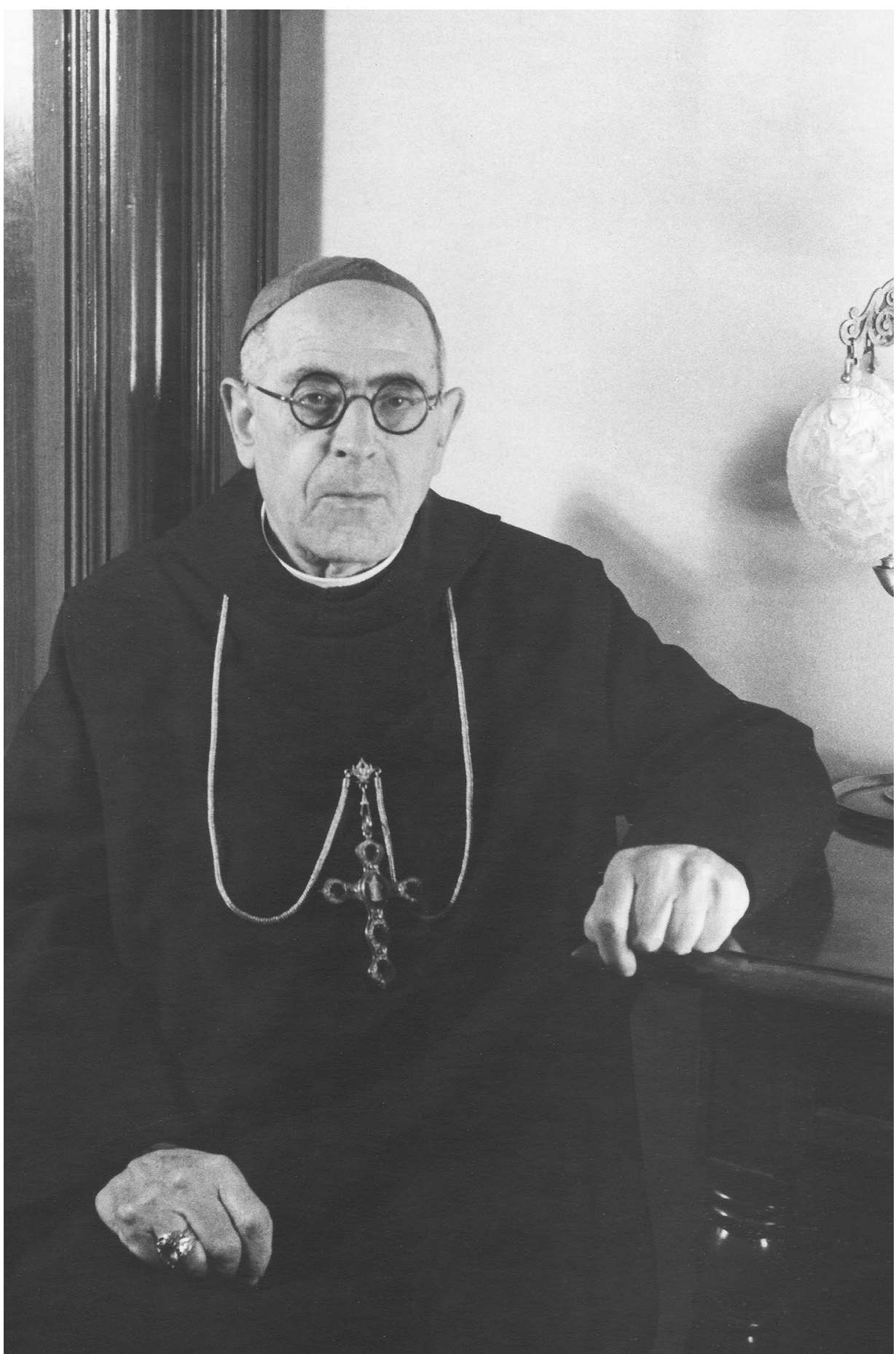

Figure 1: Abbot Catalan.

Source: Courtesy Archives of the Benedictine Community of New Norcia 72591P. 
Despite their hesitant beginnings, Neville and Catalan both devoted significant years of their lives to the state's Indigenous communities. As Chief Protector, Neville's approach to managing the Indigenous populations was heavily influenced by social and political pressures. Particularly significant were the economic and ideological imperatives that influenced Neville's preference to accommodate the state's Aboriginal populations in government-run settlements rather than on missions. ${ }^{13} \mathrm{He}$ also pursued increasingly tight controls over Aboriginal people's movements and behaviour. While the Chief Protector's disdain for missions caused understandable concern for New Norcia authorities, Neville's later promotion of policies to eliminate the mixed-descent population attracted a more ambiguous response from the mission. For his part, Abbot Catalan's oversight of New Norcia's Indigenous residents was similarly impacted by ideology - in this case deriving from religious ideals. However, the Abbot's prioritisation of sectarian adherence was at times detrimental to the Aboriginal community, and a source of frustration for Neville.

In examining the correspondence between Neville and Catalan, three major areas of friction become evident. In the first instance, as a Roman Catholic institution, New Norcia's influence within a Protestant-dominated environment created sectarian tensions that were problematic for the staunchly Anglican Neville. Second, Catalan's ability to care for the mission's Aboriginal residents was consistently hampered by his conflicted role as both an advocate for his residents and a virtual agent of the state. Finally, Neville's increasingly severe policies concerning 'tribal' and mixeddescent marriages presented dilemmas for many mission communities. Yet, as we shall see, Catalan's response to Neville's demands was predominantly guided by his commitment to sectarian integrity, rather than opposition to the 'race-based' restrictions pursued by Neville. These areas of tension are first examined separately to make sense of the complex social and political forces influencing Neville and Catalan. Considering these factors in combination, we see that this particular state-mission relationship experienced significant tensions as a result of Neville's anti-mission outlook and Catalan's defiant response. The Benedictine missionaries' vulnerability on religious grounds necessitated their compliance with Neville's directives regarding Aboriginal care, and this conflicted position heavily affected their ability to protect the Aboriginal community from severe state-imposed restrictions on their lives.

13 Haebich 1988: 157. 


\section{A Benedictine mission}

New Norcia is a small monastic town located 132 kilometres north-east of Perth. In 1846, the town was originally established as a mission by Spanish missionary Dom Rosendo Salvado. As Bernard Rooney and John Harris have described, Salvado recognised the importance of balancing Aboriginal traditions with the missionaries' Christianising aspirations. Like some of the early Lutheran missionaries, Salvado acknowledged the value in maintaining traditional Indigenous languages, and he encouraged Aboriginal people to hunt or spend time in the bush if they appeared to become unmotivated. ${ }^{14}$ As a mission community, New Norcia was perhaps most unusual in its aim to operate for the benefit of Aboriginal people without necessarily being dependent upon their labour. Unlike other institutions, New Norcia shared labour between a large number of monks and other white employees, effectively enhancing the cooperative working relationships between missionaries and Aboriginal families. ${ }^{15}$ Salvado also valued the sanctity of Aboriginal family life, and insisted on Aboriginal children remaining with their families in their own homes at night. ${ }^{16}$ These factors proved successful in fostering the Aboriginal community's willingness to entrust the care of their children to the mission as early as $1847 .{ }^{17}$

The Benedictine missionaries' initial accommodation of Indigenous culture was to lessen over time due to a combination of state regulations and mission changes instigated in the late nineteenth and early twentieth centuries. The passing of Western Australia's Aborigines Protection Act 1886 ushered in significant changes and required New Norcia to admit Aboriginal and mixed-descent children from a broader geographical area, effectively decreasing the local, family-focused character of the mission. ${ }^{18}$ In 1900, Salvado's death prompted the appointment of Dom Fulgentius Torres, who decreased New Norcia's missionary focus in his quest to transform it into a European-style monastery, a decision that created resentment amongst the mission's Aboriginal population and was criticised in the press. ${ }^{19}$ In 1906 , Torres also commenced the establishment of a Benedictine outpost at Drysdale River in the northern Kimberley region, an endeavour requiring additional oversight and financial support from New Norcia. ${ }^{20}$

14 Harris 1994: 316; Rooney 2006: 310.

15 Harris 1994: 296-97; Rooney 2006: 311.

16 Harris 1994: 296.

17 Rooney 2006: 311.

18 Harris 1994: 302-3.

19 Rooney 2006: 315; Haebich 1988: 17.

20 Durack 1969: 212, 215; Hutchison 1995: 85. 
The passing of the Western Australian Aborigines Act 1905 contributed to a new social and political atmosphere that ultimately reshaped New Norcia's relationship with the state. This legislation effectively laid the cornerstone of legal parameters that were designed to segregate Aboriginal populations from the wider community. In particular, the 1905 Act appointed the Chief Protector of Aborigines as the legal guardian of all Aboriginal and 'half-caste ${ }^{21}$ children under 16 years of age, legally sanctioning the removal of children from their families and their placement in institutional care. ${ }^{22}$ In 1906, New Norcia's Abbot Torres was granted Protector status by then Chief Protector Henry Prinsep in recognition of the important role the mission was to play in supporting government policy. ${ }^{23}$ However, it was under Neville's administration that the full powers of the Aborigines Department were to significantly impact upon mission authorities - including New Norcia and the Drysdale River Mission.

\section{'But should we the oldest and faithful Aborigines Institution in W.A., be singled out for slaughter because we are Catholics th[e]n it is time for us to rebel'24}

From his earliest experience of the Western Australian mission, Catalan was aware of New Norciass vulnerability both as a mission and a religious organisation, and it would seem that his fears were well-founded. Upon his appointment as Chief Protector, Neville was guided by Minister Underwood's anti-mission stance, and a desire to increase the professionalism of the Aborigines Department while also reducing departmental expenditure. ${ }^{25}$ Neville's preference to accommodate the state's Aboriginal populations in government-run settlements signalled a significant threat to mission communities. The major impetus of Neville's preferred Native Settlement Scheme was to segregate Aborigines from the wider community with as little financial outlay as possible. ${ }^{26}$ Neville predicted that the settlements would be phased out after two or three generations as the older people died off and the younger Aboriginal people joined the wider community. However, the interim arrangement was for all Aboriginal people to submit to the direct control of the

\footnotetext{
21 Terms such as 'full-blood' and 'half-caste', which were once commonly used to differentiate on the basis of parentage, are considered offensive and are no longer used in either a common or official sense. Such terminology does not reflect the values of the author or this journal, and is therefore presented between single quotation marks to denote its contentious status.

22 Haebich and Delroy 1999: 20-21.

23 Prinsep to Torres, 20 June 1906, ABCNN 05118.

24 Catalan to Colonial Secretary Drew, 17 August 1915, ABCNN 05118.

25 Haebich 1988: 157.

26 Haebich 1988: 157.
} 
Aborigines Department and accept settlements as the focal point of their lives. ${ }^{27}$ While rumours of poor living conditions, lack of freedom and violent treatment saw many Aboriginal people refusing to move to settlements, vulnerable families, especially those reliant upon rations, submitted to the department's plans. ${ }^{28}$

The settlement scheme enabled Neville to reduce mission subsidies, which were halved between 1915 and $1920 .{ }^{29}$ While only those children referred to missions by the Aborigines Department were to be subsidised, Neville's belief that funds should support practical and vocational skills for Aboriginal children, rather than the Christianity prioritised at missions, made such referrals uncommon. Most missions closed during this period, with New Norcia the only mission to survive, albeit with cuts to its funding. ${ }^{30}$ In responding to New Norcia's funding cuts, Catalan appealed to Colonial Secretary Drew, also a Catholic, declaring, 'should we the oldest and faithful Aborigines Institution in W. A. be singled out for slaughter because we are Catholics than $[s i c]$ it is time for us to rebel'. ${ }^{31}$ The Abbot clearly interpreted Neville's cuts to the mission's subsidies as resulting from an anti-Catholic bias, rather than as reflecting his more general anti-mission position.

This is not to say that Neville rejected all forms of spiritual guidance for his Aboriginal charges. Within the vicinity of New Norcia, the Moore River Native Settlement employed Church of England missionary workers to provide Christian guidance to the settlement community. As Neville later explained, his preference was to 'ensure that in the future our missionaries and mission workers are British in origin and sentiment or at least possess the same outlook as ourselves [public servants]'. ${ }^{32}$ With respect to the Moore River Settlement, this preference for British missionaries ignored New Norcia's long history of involvement with the local Aboriginal population. ${ }^{33}$ However, Neville evidently allowed New Norcia priests to visit the Moore River Settlement on occasion, for the benefit of Catholic residents, a situation that Catalan and New Norcia priests exploited as a way of increasing Catholic influence among the settlement's residents. In fact, the priests' determined, and at times defiant, actions at the Moore River Settlement were to ignite significant tensions between Catalan and Neville during the 1920 s. $^{34}$

27 Haebich 1988: 157-58.

28 Haebich 1988: 171-72.

29 Haebich 1988: 166.

30 Haebich 1988: 166-68.

31 Catalan to Drew, 17 August 1915.

32 Neville 1947: 103-4, 120.

33 Harris 1994: 284-87; Haebich 1988: 168.

34 Catalan to Neville, 10 February 1928, ABCNN 01430. 


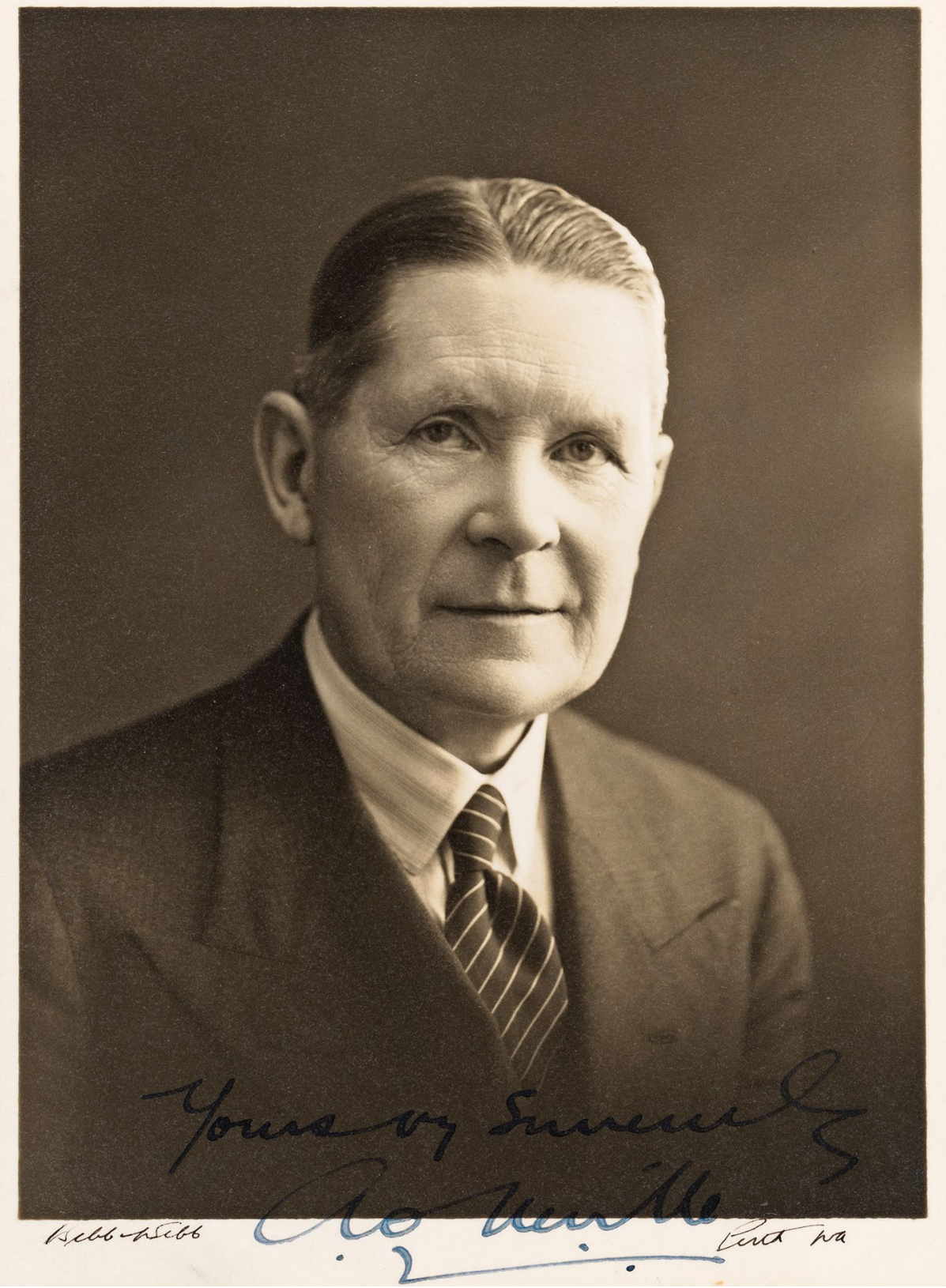

Figure 2: Mr A.O. Neville, Commissioner of Native Affairs.

Source: Courtesy State Library of Western Australia, 5000B. 


\section{'I do not want to turn, but the Father is trying to make me do so against my wish'35}

On several occasions, New Norcia priests attempted to baptise children who, according to Neville, had previously been baptised by Church of England ministers, or whose parents did not identify as Roman Catholic. ${ }^{36}$ Tense communications between Neville and Catalan continued throughout the 1930s as the Abbot referred to a distinct anti-Catholic bias in the actions of authorities, and accused Neville of contravening the Aboriginal people's 'right to religious freedom'. ${ }^{37}$ Catalan's reference to Aboriginal people's freedom in this regard is somewhat ironic given the lack of consideration for their wishes shown by either Neville or the missionaries. While critiquing the priests' heavy-handed approach to Aboriginal families, Neville's own failure to seek and clarify the preferences of Aboriginal parents in these matters effectively denied these families any autonomy regarding their religious adherence. ${ }^{38}$ New Norcia priests similarly disregarded Aboriginal families' interests when justifying that their strenuous efforts to baptise the children of mixed-faith marriages were legitimate and indeed necessary in their struggle to maintain the Catholic Church's relevance amongst the local Indigenous people. The absence of Aboriginal voices within the correspondence considerably hampers our ability to interpret their response to these incidents. Understandably, Aboriginal families might have felt bemused or even outraged regarding the priests' actions. It is also possible that some may have welcomed the priests' intervention to properly acknowledge their Catholic adherence, or offer correction to baptisms possibly enforced by settlement authorities.

During the 1930s, New Norcia priests' attitudes towards Aboriginal couples at the Moore River Settlement reinforced tensions between Neville and Catalan. Secular staff employed at the Moore River Settlement alerted the Aborigines Department to a number of incidents in which the visiting New Norcia priests appeared to be interfering in the lives of married couples. Moore River staff members were disturbed that the priests were trying to induce non-Catholic partners to convert to Catholicism. ${ }^{39}$ While the priests maintained that they were attempting to redress the increasing number of mixed-faith marriages at the settlement, the Aborigines Department was particularly concerned by the New Norcia priests' defiance when reproached by settlement staff, and requested Catalan's cooperation in reprimanding the offending clergy. ${ }^{40}$ Catalan's response, however, was neither apologetic nor

35 Williams to Neville, 11 February 1935, ABCNN 05120.

36 Neville to Catalan, 27 February 1928, ABCNN 05118; Catalan to Neville, 15 October 1934, ABCNN

01436; Neville to Catalan, 13 March 1937, ABCNN 05120.

37 Catalan to Neville, 15 October 1934.

38 Neville to Catalan, 13 March 1937.

39 Bray to Catalan, 21 July 1934, ABCNN 05119; Neville to Catalan, 25 February 1935, ABCNN 05120.

40 Bray to Catalan, 21 July 1934. 
regretful, and demonstrated considerable resistance to departmental authority. On one occasion, stating that the couple in question had not 'accomplished the conditions required for their matrimony's validity', Catalan endorsed his priest's actions as a legitimate attempt to validate a marriage that was not recognised by the Catholic Church. ${ }^{41}$

While we rarely hear Aboriginal voices within these state-mission communications, on one occasion Neville included an Aboriginal man's written statement to support his own criticism of the priests' actions. In objecting to attempts by a New Norcia priest to force his religious conversion, Alfred Williams asserted 'he [the priest] ought to be satisfied as my wife is an R.C. and all my children too'. ${ }^{42}$ However, Catalan maintained that it was the Moore River Settlement authorities who were acting unfairly, by not giving due consideration to Catholic requirements in the event of a mixed-faith marriage. ${ }^{43}$ While Williams's protest failed to attract Catalan's sympathy or remorse, Neville's unusual inclusion of the statement provides a valuable source of Aboriginal perspective on the priest's actions. Aside from the obvious resentment in his statement, 'I do not want to turn [to Catholicism] but the Father is trying to make me do so against my wish', ${ }^{44}$ Williams's letter expresses his own nonchalance regarding his family's inconsistent religious adherence, a point that no doubt concerned Catalan.

Catalan's resistant stance during these incidents reflected his own considerable anxiety regarding the impact of mixed-faith marriages on Catholic identity within the Aboriginal community. Such marriages had become a sensitive issue for Catholic priests since the Ne Temere papal decree had come into effect in $1908 .{ }^{45}$ This decree stipulated that marriages either between Catholics or between a Catholic and a non-Catholic person were not valid before God and church, unless they were contracted in the presence of a Catholic pastor. ${ }^{46}$ Importantly, this decree had attracted opposition from Protestant organisations due to its defiance of state power that recognised the validity of the civil and Protestant components of mixed-faith marriages. ${ }^{47}$ Catalan was also concerned about certain assurances that needed to be obtained prior to the marriage ceremony, such as the promise required by the non-Catholic party to raise his or her children in the Catholic faith. ${ }^{48}$ As with the episodes relating to baptism, Catalan's adherence to Catholicism largely outweighed his concern for the Aboriginal people's own wishes. In responding to Neville's claims

41 Catalan to Bray, 30 July 1934, ABCNN 01436.

42 Williams to Neville, 11 February 1935, ABCNN 05120.

43 Catalan to Neville, 4 March 1935, ABCNN 01436.

44 Williams to Neville, 11 February 1935.

45 Mol 1970: 293.

46 Mol 1970: 293; O’Farrell 1969: 240-41.

47 O'Farrell 1969: 242.

48 Catalan to Neville, 4 March 1935; Mol 1970: 293. 
regarding Alfred Williams's objections to Catholic conversion, Catalan dismissed the concerns, arguing that they were 'founded merely on the word of a native with no witnesses' ${ }^{49}$

During the late 1930s, Catalan's defiant pursuit of greater Catholic influence at the Moore River Settlement drove his request to build a dedicated Catholic hall for the settlement's residents and Catholic priests. Surprisingly, Neville agreed to the proposal in February 1939. Although Chief Secretary Kitson had rejected the plan in February 1938, the Chief Protector, in his final year in office, made a small concession by granting conditional endorsement for the building. ${ }^{50}$ Perhaps Neville was influenced (or exhausted) by Catalan's determined lobbying. Neville presumably weighed his concession against the opportunity to attract and maintain New Norcia's compliance on issues of greater significance to him, such as the oversight of the mission's Aboriginal residents and the prevention of marriages between mixeddescent and 'full' Aboriginal people.

\section{'I shall be glad to know how it was that the seriousness of her condition was not discovered earlier'51}

The relationship between Neville and New Norcia substantially complicated the mission's level of care for Aboriginal residents. Catalan's conflicted intermediary role was evident in his attempts to meet their needs despite the financial and regulatory constraints imposed by Neville. During earlier interactions, this situation was evidenced by the Abbot's obvious difficulty in seeking urgent health care for his residents while adhering to Neville's pedantic administrative demands. Neville's tighter administration of mission subsidies brought increased scrutiny to New Norcia's operations and finances, and raised considerable concerns for Catalan regarding the mission's financial viability. ${ }^{52}$ Perhaps sensing the mission's vulnerability under Neville's reforms, Catalan was initially compliant with departmental processes regarding the care of New Norcia's Aboriginal residents.

On one such occasion during 1918, Catalan visited Neville's city office seeking permission for 19-year-old Mary Graham to go to a sanatorium for more specialised care, as she was gravely ill. ${ }^{53}$ Neville's insistence on a doctor's certificate, and Catalan's difficulty in obtaining one, delayed the young woman's treatment for some two months. Tragically, Mary passed away just four days before Catalan finally

\footnotetext{
Catalan to Neville, 4 March 1935.

0 Kitson to Catalan, 22 February 1938, ABCNN 05119; Neville to Catalan, 17 February 1939, ABCNN 05119.

51 Neville to Catalan, 9 August 1918, ABCNN 05120.

52 Biskup 1973: 155; Haebich 1988: 167.

53 Catalan to Neville, 14 August 1918, ABCNN 01420.
} 
received Neville's permission to place her in the sanatorium. ${ }^{54}$ Considering Catalan's attempts to balance Neville's requirements with Mary's critical need for care, the Abbot was understandably perplexed by Neville's inquiry, 'I shall be glad to know how it was that the seriousness of her condition was not discovered earlier' ${ }^{55}$ Mary's death emphasised the considerable discrepancy between Neville's pursuit of greater administrative efficiency and the lived experiences of those individuals whom these so-called 'efficiencies' had attempted to assist. While Neville remained rigid in his demands for Catalan to follow proper protocols, Catalan's early compliance had altered by 1937, as shown when he acted on the rapidly declining health of a young girl named Milly. ${ }^{56}$ Catalan's decision to admit Milly to the children's hospital without notifying the Aborigines Department was criticised and, following the girl's eventual death from her illness, the Abbot was reprimanded for defying proper procedure, and ordered to reimburse the department for her funeral expenses. ${ }^{57}$

Correspondence relating to the health of New Norcia's residents also reveals the extent to which they attracted departmental surveillance when receiving medical treatment away from the mission. Neville was particularly concerned that New Norcia's residents could potentially evade departmental oversight when receiving medical attention in Perth, and therefore sought increased cooperation from Catalan in monitoring their movements and behaviour. As with other Aboriginal communities in Western Australia, eye problems such as trachoma were endemic at New Norcia, and those residents afflicted with the condition were occasionally sent to Perth for treatment. ${ }^{58}$ Indeed, the young woman referred to at the beginning of this article, Eliza George, had been sent to Perth in 1930 to receive such treatment. Like other young Aboriginal women, she was accommodated in a governmentdesignated boarding house. ${ }^{59}$ Eliza first attracted Neville's displeasure when she unexpectedly returned to New Norcia without requesting the Chief Protector's permission. Neville was particularly annoyed at the mission's communication failure, and the unnecessary accommodation expenses incurred by his department. ${ }^{60}$

Catalan's difficult intermediary role was evident in his response to Neville, in which he attempted to negotiate an agreeable situation for both Eliza and the Chief Protector. Catalan explained that Eliza had returned to New Norcia of her own accord, and that he had tried to convince her to continue her treatment in Perth until the hospital authorities formally dismissed her. He also acknowledged that the

\footnotetext{
54 Catalan to Neville, 14 August 1918.

55 Neville to Catalan, 9 August 1918, ABCNN 05120.

56 Neville to Catalan, 15 March 1927, ABCNN 05120; Neville to Catalan, 15 April 1932, ABCNN 05120.

57 Bray to Catalan, 19 January 1937, ABCNN 05119; Catalan to Bray, 24 January 1937, ABCNN 01438.

58 Briscoe 2003: 179-80; Neville to Catalan, 13 May 1931, ABCNN 05120; Catalan to Neville, 2 July 1932 , ABCNN 01433; Catalan to Neville, 1 August 1937, ABCNN 01438; Catalan to Bray, 27 September 1940, ABCNN 01442.

59 Bray to Catalan, 26 July 1932, ABCNN 05120; Kinnane 2003: 203.

60 Neville to Catalan, 13 May 1931.
} 
arrangement had strained departmental finances, and suggested that Eliza remain at the mission in between her three-monthly appointments in Perth. ${ }^{61}$ Curiously, however, Neville disregarded Catalan's suggestion, and directed that Eliza should return to Perth, adding 'she must understand distinctly that when she reaches Perth she is under my control, and must do as she is told'. ${ }^{62}$ Neville's concern for Eliza might well have concluded at that point but for Catalan's further request, in July 1932, to allow another woman, Josephine Wallace, to go to Perth for treatment for a similar eye complaint. ${ }^{63}$ Catalan's letter reminded Neville that Eliza, having returned to Perth in 1931, was still receiving treatment and that her stay had now been ongoing for the past two-and-a-half years. In his response to Catalan, Neville noted that Eliza's treatment had come at considerable cost to the department, and recognising that Josephine now required similar care, decided not to approve departmental support for Josephine's treatment. Neville explained that New Norcia authorities were now liable for Josephine's treatment costs because she had lived at the mission nearly all of her 40 years. $^{64}$

Clearly angered by Neville's response, Catalan requested the intervention of Chief Secretary Charles Baxter. ${ }^{65}$ While Baxter eventually endorsed some limited departmental support for Josephine's treatment, the Aborigines Department terminated Eliza's treatment in Perth. ${ }^{66}$ However, this was not the end of the story for Eliza who, upon learning of her imminent return to New Norcia, escaped from the Perth boarding house. When apprehended by a police officer, Eliza claimed that she was the daughter of a 'half-caste' by a white father, and therefore was not subject to the provisions of the Aborigines Act. ${ }^{67}$ Deputy Chief Protector Bray, who was in charge during a period of Neville's absence, asserted that Eliza was being influenced by others who had offered to help her take legal action to clarify her position if the department attempted to send her back to New Norcia. ${ }^{68}$ Bray was anxious about the delicate legal situation affecting both the department and New Norcia, and the possible repercussions if it was discovered that significant funds had been spent on the care of a person deemed non-Aboriginal. ${ }^{69}$

Despite Neville's best efforts to control his Aboriginal charges, this episode accentuated his need to gain the support and compliance of mission authorities. What might initially be regarded as a routine matter involving a young woman's health care offers valuable insights into this complex state-mission relationship

61 Catalan to Neville, 18 May 1931, ABCNN 01432.

62 Neville to Catalan, 21 May 1931, ABCNN 05120.

63 Catalan to Neville, 2 July 1932.

64 Neville to Catalan, 13 July 1932, ABCNN 05120

65 Catalan to Baxter, 25 July 1932, ABCNN 01433.

66 Baxter to Catalan, 4 August 1932, ABCNN 05119; Bray to Catalan, 26 July 1932, ABCNN 05120.

67 Bray to Catalan, 25 August 1932, ABCNN 05120.

68 Bray to Catalan, 25 August 1932.

69 Bray to Catalan, 25 August 1932. 
and the flow-on effects for Aboriginal residents. Catalan evidently performed a complicated role as both an advocate for his residents, and in his duty to assist the Aborigines Department. In attempting to help resolve the department's dilemma, Catalan supplied the available details of Elizas parentage - which, incidentally, gave no indication as to her 'racial' make-up. He also explained that the young woman would always be welcomed at New Norcia. ${ }^{70}$ While Eliza did eventually visit the mission again, she did not remain there for long. Catalan's final correspondence to Bray on the matter revealed his disappointment at having lost contact with Eliza, and his obligation to inform the department of her departure. ${ }^{71}$

Eliza's actions during this incident are particularly intriguing. Not only did she demonstrate considerable assertiveness in questioning the legality of the department's control over her life, she also rejected the idea of submitting once again to mission authorities. Furthermore, Eliza's reference to her 'racial' make-up and her confidence in challenging departmental regulations are indicative of the Indigenous community's awareness of Neville's increasingly restrictive 'race-based' controls and their implications. In the early 1930s, Eliza was able to escape the clutches of the Aborigines Department, and indeed the mission, at a time when her particular 'racial' make-up positioned her outside Neville's sphere of control. However, the Chief Protector's need for greater authority in solving the growing 'half-caste problem' was to become a major concern for Aboriginal families and New Norcia as the 1930s progressed.

\section{'I suppose you have heard about Mr Neville the Protector. He is taking every girl that is fair from their mothers ${ }^{72}$}

Throughout his term, Neville was confronted by the deficiencies of the Western Australian Aborigines Act 1905 that had been formulated on the false assumption of the Aboriginal population's inevitable extinction. ${ }^{73}$ In fact, the rapidly increasing 'half-caste' population had raised significant challenges for Neville in his attempts to accommodate prevailing societal attitudes within his policy decisions. Essentially, these mixed-descent people were considered too black to join white society yet too white to be left within Aboriginal communities. Neville called for the policy to shift from its earlier focus on segregating Aborigines from the potential contamination posed by white society. Instead, he advocated a policy in which Aborigines of mixed

70 Catalan to Bray, 27 August 1932, ABCNN 01433.

71 Catalan to Bray, 10 September 1932, ABCNN 01433.

72 Gregory to Catalan, 16 March 1937, ABCNN 05120.

73 Tomlinson 2008: Abstract. 
descent would be absorbed into the white population. ${ }^{74}$ Whilst broader support for such measures was slow to gain momentum, in 1933 the parliament voted for a royal commission to investigate the condition and treatment of Aborigines. ${ }^{75}$ Perth Magistrate Henry Doyle Moseley undertook the royal commission in 1934, and his report was tabled in parliament in $1935 .{ }^{76}$ Importantly, the report acknowledged the need for amendments to existing legislation as Neville had long been arguing.

The Native Administration Act 1905-1936 (WA) combined recommendations from both Moseley and Neville. The legislation instituted changes that provided Neville with guardianship of all legitimate and illegitimate Aboriginal and 'halfcaste' children up to 21 years of age, regardless of whether or not the child had a living parent or relative. ${ }^{77}$ The Act also included a broader definition of 'native' to encompass a wide range of Aboriginal people of part descent who had not been subject to the 1905 Act. $^{78}$ The extension of Neville's legal powers allowed him to separate mixed-descent children from all Aboriginal influences, and facilitated their assimilation into white society. As Holland explains, Neville was particularly concerned about the impact of missions on his plans for assimilation. Not only did missionaries encourage marriages, regardless of descent, they endeavoured to create 'segregated, self-perpetuating Aboriginal communities' ${ }^{79}$ Neville instead maintained that confining people of mixed descent to settlements enabled closer departmental oversight of their marriages while also providing opportunities for them to work and interact amongst the general community. ${ }^{80}$ Neville's determination to accommodate mixed-descent children in government settlements rather than on missions was to significantly impact upon New Norcia's ability to assist parents seeking protection for their mixed-descent children.

In March 1937, local Aboriginal man Jonathon Gregory recognised the consequences of Neville's increased authority and made a desperate request for Catalan to admit his 'fair-skinned' daughter, Hannah, to New Norcia. Gregory elaborated, 'I suppose you have heard about Mr Neville the Protector. He is taking every girl that is fair from their mothers' ${ }^{81}$ This was not the first time Catalan was approached to help Aboriginal families fearing the removal of their children. Responding to a similar

\footnotetext{
74 Tomlinson 2008: Abstract.

75 Haebich 1988: 327-28.

76 Haebich 1988: 328, 337; Western Australia, Royal Commission 1935.

77 Native Administration Act 1905-1936 (WA), 'To Remove and Protect: Western Australia: Legislation / Key Provisions', Australian Institute of Aboriginal and Torres Strait Islanders (AIATSIS), aiatsis.gov.au/collections/ collections-online/digitised-collections/remove-and-protect/western-australia (accessed 1 September 2017).

78 Haebich 1988: 349; Native Administration Act 1905-1936 (WA), 'To Remove and Protect', AIATSIS, aiatsis. gov.au/sites/default/files/docs/digitised_collections/remove/52794.pdf (accessed 1 September 2017).

79 Holland 2015: 202.

80 Holland 2015: 202-3.

81 Gregory to Catalan, 16 March 1937.
} 
request in 1933, the Abbot had been unable to accommodate more children at that time due to financial constraints imposed by the Aborigines Department. His regretful reply stated:

I wish I could do something for the half caste May Brown as well as for other natives, who are asking me to do something for them, especially now when it seems they are afraid to be removed to Moore Settlement. ${ }^{82}$

Aboriginal families were becoming increasingly fearful of having their children removed to the known appalling conditions of the Moore River Settlement where residents suffered from inadequate food, accommodation and health care, and received cruel treatment from settlement authorities. ${ }^{83}$

By 1937, Catalan was able to accommodate Gregory's daughter, and Hannah was admitted to New Norcia on 26 March. ${ }^{84}$ However, the arrangement was to be short-lived. Only one month later, Catalan was advised that Neville had decided to remove Hannah from New Norcia as she was 'a quadroon, and her only hope [was] to remove her altogether from the Toodyay District and association with natives' ${ }^{85}$ Catalan's subsequent communication to Gregory revealed his regret and helplessness at the hands of the department, and particularly his concern regarding the girl's ability to maintain her faith unless placed in a Catholic home or school. ${ }^{86}$ Despite Catalan's assurances to Neville of Hannah's preference to remain at New Norcia, he regretfully acknowledged Neville's authority under the Act, and conceded that mission authorities would be in no position to stop him should he remain convinced of the need to remove her from New Norcia. ${ }^{87}$

When directly confronted by the impacts of Neville's decisions on New Norcia's Aboriginal community, it appears Catalan's sympathy was with mission residents. He seems to have genuinely cared for the mission's Aboriginal residents and sought as much assistance for them as possible. Essentially, his efforts were considerably hampered by the financial and administrative restrictions enforced by the Aborigines Department, as well as Neville's legal authority. While he may have been able to resist departmental interference regarding the missionaries' religious influence, Catalan's attempts to advocate on behalf of mission residents were largely ineffective.

82 Catalan to Smith, 16 February 1933, ABCNN 01434.

83 Haebich 1988: 207, 310-11, 334-35.

84 Catalan to Neville, 24 April 1937, ABCNN 01438.

85 Bray to Catalan, 20 April 1937, ABCNN 05120.

86 Catalan to Gregory, 23 April 1937, ABCNN 01438.

87 Catalan to Neville, 24 April 1937. 


\section{'But we have no half-caste girls for them at Drysdale, and as they are excellent boys I want to get them the wives they want's8}

Examining the Benedictine missionaries' approach to mixed-descent and Aboriginal marriage is particularly revealing of their priorities with respect to Aboriginal welfare. Interactions between Neville and Catalan regarding mixed-descent relationships were especially complicated due to the missionaries' reliance on marriage as a civilising force, and the Indigenous population's varying levels of Aboriginal descent, particularly at New Norcia's outpost Drysdale River Mission. Neville's earlier years in the Department of Immigration and Tourism, and particularly his exposure to the Immigration Restriction Act 1901 (Cth), had established his strong commitment to 'white Australia' ideals. Neville demonstrated this commitment through his strict adherence to the marriage regulations outlined under the Aborigines Act 1905 stipulating that the Chief Protector's permission was required for any marriage between an Aboriginal woman and a non-Aboriginal man. ${ }^{89}$ The early twentieth-century requirement to control mixed-descent relationships reflected the new nation's fears regarding miscegenation, and particularly the threat posed by the 'coloured half-caste' population. ${ }^{90}$

The diverse character of the Aboriginal communities under Neville's control produced further complications for the Chief Protector. During his 1916 tour of the Kimberley, Neville opined that the strength and vitality of the Kimberley tribespeople needed protection from white contamination. ${ }^{91}$ He particularly regarded the encroachment of missions within these areas as a significant threat to the cultural and 'racial' integrity of the 'full-blood' tribes. ${ }^{92}$ Not only did Neville's viewpoint challenge the very existence of missions amongst Aboriginal communities, it also threatened mission-arranged marriages as one of the key strategies adopted by missionaries in Christianising and civilising the Aboriginal populations. As Felicity Jensz explains, missionaries emphasised the marriage of Indigenous mission residents as a way of reinforcing gendered European and Christian codes of behaviour, with the hope that married couples would then remain with the mission and become useful role models for local Aboriginal people yet to be converted. ${ }^{93}$

88 Catalan to Colonial Secretary Colebatch, 22 December 1917, ABCNN 01418.

89 Aborigines Act 1905 (WA), s. 42.

90 Ellinghaus 2003: 186-88.

91 Jacobs 1990: 71.

92 Neville 1947: 63-66.

93 Jensz 2010: 39-41. 
In 1917, Abbot Catalan's request to arrange marriages between residents of the Drysdale River and Beagle Bay missions received Neville's strong opposition and created significant state-mission tensions. On this occasion, Catalan had attempted to transfer four mixed-descent girls from the Beagle Bay Mission as potential wives for four young men at the Drysdale River Mission (also of mixed descent) due to an absence of eligible mixed-descent women in that vicinity. ${ }^{94}$ Neville justified his opposition to the plan by alluding to the possible dangers arising from moving the young mixed-descent women to a predominantly 'full-blood' community. ${ }^{95}$ When reflecting upon the event after his retirement, Neville explained his repugnance to the appearance of a 'mass marriage' in this instance, which he regarded as a deviation from Christian principle. ${ }^{96}$

Abbot Catalan, however, saw no conflict with Christian principle. In what had become a typical course of action during this early period of Neville's term, Catalan requested ministerial intervention for his proposal. He insisted to Colonial Secretary Colebatch:

These boys are most of them, of marriageable age and would be better in every respect, married ... But we have no half-caste girls for them at Drysdale, and as they are excellent boys I want to get them the wives they want. ${ }^{97}$

Catalan assured Colebatch that the girls would not be forced into marriage and would be returned to Beagle Bay if they preferred not to stay at the Drysdale River Mission. ${ }^{98} \mathrm{He}$ also explained that during his previous visit to Beagle Bay many of the girls had been agreeable to his idea. ${ }^{99}$ Eventually, the Colonial Secretary formulated a compromise allowing the young men from Drysdale River to relocate to the Beagle Bay Mission for the purpose of marriage, an outcome that Catalan gratefully accepted. ${ }^{100}$

While this incident was ultimately resolved, the arguments presented by both Catalan and Neville reveal their contrasting attitudes towards Aboriginal men, and the potential for miscegenation. Catalan's emphasis on the benefits of marriage for the mixed-descent men ran counter to the official preoccupation with the Aboriginal female's role in reproduction that predominated during the twentieth century. More predictably, Neville's insensitivity to the plight of the men at Drysdale River reflected the typical bureaucratic attitude that denied the role of Aboriginal (including mixed-descent) men as husbands and fathers, such an acknowledgement

\footnotetext{
94 Neville 1947: 66; The four 'half-caste' boys had been sent to the Drysdale River Mission in 1909 during Chief Protector Isdell's drive to remove 'half-caste' children in the Fitzroy Crossing area. See Choo 1997: 25.

95 Catalan to Colebatch, 30 September 1918, ABCNN 01420.

96 Neville 1947: 66.

97 Catalan to Colonial Secretary Colebatch, 22 December 1917.

98 Catalan to Colebatch, 22 December 1917.

99 Catalan to Colebatch, 22 December 1917.

100 Catalan to Colebatch, 5 August 1918, ABCNN 01420; Catalan to Colebatch, 30 September 1918.
} 
being counterproductive to the aims of Aboriginal policy that assigned the paternal role to the state. ${ }^{101} \mathrm{~A}$ further complication for Neville was the idea that these couples, and their offspring, would remain on the mission, in close proximity to a 'fullblood' community. That outcome was incompatible with official plans to separate the 'half-caste' and 'full-blood' populations, and assimilate 'half-castes' to ensure their transformation into useful members of the broader community. ${ }^{102}$

\section{'Offered flour, tobacco, and thin brushes for the paint, you know, but they had to stay with us, the missionaries. And afterwards they had to be free to marry the one they wanted' 103}

Involvement in Aboriginal marriages by either the state or missions also raised the question of how best to deal with existing 'tribal' marriage practices. Anthropologists categorise traditional Aboriginal marriage systems as 'gerentocratically polygynous', meaning that older Aboriginal men were entitled to more than one, and sometimes several wives, whileyoung men had no wives at all. ${ }^{104}$ While Neville was uncomfortable with the polygamous nature of these marriages, he acknowledged the often violent consequences arising either from Aboriginal transgressions, or state or missionary interference. Placing heavy emphasis on his role as 'protector', Neville was adamant that any Christian marriages contracted between Aboriginal couples should first consider and respect 'tribal' law. ${ }^{105}$ As Choo explains, Drysdale River missionaries shared Neville's concerns with 'tribal' marriages, and were also, outwardly at least, committed to avoiding interference in marriages wherever the Aboriginal people were not Christian. However, the missionaries played an active role in the marriages of Aboriginal people who identified as Christian, paying particular attention to the requirement for the men to choose only one wife. ${ }^{106}$

The Drysdale River missionaries' outward acceptance of 'tribal' considerations contradicted their beliefs that such customs contributed to dangerously low populations amongst the Aboriginal community. ${ }^{107}$ According to former Drysdale River missionary Father Seraphim Sanz, who was interviewed by Choo in the 1990s, the missionaries at Drysdale River were deeply concerned about the practice of 'promising' young girls to old men, which produced an age disparity that disastrously

101 Haskins 2003: 110-11.

102 Haebich 1988: 150-51, 157-58.

103 Sanz, 9 April 1992: tape 1, as quoted in Choo 2001: 205.

104 Choo 2001: 192.

105 Tomlinson 2008: 247-48.

106 Choo 2001: 202.

107 Choo 2001: 203-4. 
affected their prospects for successful reproduction. ${ }^{108}$ Their solution involved convincing Aboriginal families to hand over their children for the missionaries to rear, thereby preserving the Aboriginal population in the area and developing a viable Catholic community. ${ }^{109}$ First envisaged as a long-term solution during the early 1930s, missionaries began to keep the children when they visited the mission with their parents. As Father Sanz later explained:

Offered flour, tobacco, and thin brushes for the paint, you know, but they [the children] had to stay with us, the missionaries. And afterwards they had to be free to marry the one they wanted. ${ }^{110}$

Throughout Neville's term, the Drysdale River missionaries' scheme escaped the scrutiny of the Aborigines Department, probably due to the mission's remote location and the fact that the children had not yet reached marriageable age. However, violations of 'tribal' considerations in marriages performed in the early 1940s resulted in several Aboriginal deaths, attracting the ire of Neville's successor, Francis Bray. ${ }^{111}$ Bray subsequently arranged an investigation into the Drysdale River missionaries' breach of the Native Administration Act 1905-1936 (WA), the results of which influenced the tightening of administrative and reporting procedures regarding marriage regulations. ${ }^{112}$

\section{Halting the 'half-caste' population}

Aside from Neville's ongoing commitment to protect the 'full-blood' Aboriginal population, he was particularly concerned about the increasing mixed-descent population. Neville had continually questioned the effectiveness of existing legislation in preventing white men's exploitation of Aboriginal and 'half-caste' women and the consequent mixed-descent offspring. ${ }^{113}$ From the late 1920 s, he began to explore more extreme solutions to halt the 'half-caste' population based on eugenic theories that had gained prominence within the scientific community. Neville adopted these theories and advocated a policy of 'biological absorption' involving 'breeding out the colour' by encouraging 'half-castes' to marry and reproduce with lighter rather than darker-skinned people. ${ }^{114}$ However, for 'full-blood' populations, Neville's policy of 'biological absorption' required their ongoing separation from mixeddescent populations. ${ }^{115}$

\footnotetext{
108 Choo 2001: 203.

109 Sanz, 29 November 1993, as quoted in Choo 2001: 203, 239.

110 Sanz, 9 April 1992: tape 1, as quoted in Choo 2001: 205.

111 Choo 2001: 186-88, 216; Bray to Catalan, 1 May 1943; Bray to Catalan, 27 May 1943, ABCNN 05119.

112 Choo 2001: 229-30.

113 Jacobs 1990: 185-86.

114 Zogbaum 2003: 132; Haebich 2000: 279; Haebich 1988: 351; Jacobs 1990: 193-94.

115 Neville 1947: 56.
} 
Neville's complicated attitudes towards mixed-descent marriages had a significant impact on missions where residents were free to select their own marital partner regardless of 'race'. ${ }^{116}$ Assessing the Benedictine missionaries' reactions to Neville's marriage controls is assisted by comparative studies of other mission communities in Western Australia, such as the Mount Margaret missionaries who were vocal opponents of Neville's state-imposed marriage requirements. Holland has written extensively on Mount Margaret teacher and activist Mary Bennett, whose outspoken challenge to Neville's attitudes on 'tribal' marriage practices and 'racial' absorption contributed to the mission's rapidly declining relationship with Neville. ${ }^{117}$ While the Moseley royal commission and changes to the Aborigines Act were indicative of the harder line Neville was pursuing with respect to mixed-descent intercourse and marriage, the final breakdown of Neville's relationship with the Mount Margaret Mission came from Neville's attack on missions at the Aboriginal Welfare Conference of Commonwealth and State Aboriginal Authorities in April 1937. During this conference, Neville openly criticised the attitudes of missions and their incompatibility with his plans. ${ }^{118}$ The following year, Neville introduced 150 additional regulations associated with the Native Administration Act, including the requirement for missions to obtain a licence from Neville's department. These measures intended to remove any sense of autonomy previously enjoyed by mission communities. ${ }^{119}$

In comparison with the bitter arguments played out between Neville and the Mount Margaret Mission over mixed-descent marriage, interactions between Neville and authorities at the Benedictine missions were remarkably amicable. Communications predominantly focused on obtaining appropriate permissions and notification of marriages performed at the mission. ${ }^{120}$ In some instances, Neville requested marriage details to ascertain the 'racial' make-up of his Aboriginal charges, and Catalan's response was typically obliging and efficient. ${ }^{121}$ In stark contrast to impassioned arguments that characterised the Mount Margaret Mission-Neville relationship, New Norcia's interactions with Neville regarding Aboriginal marriage had become highly bureaucratic. Aside from the clandestine attempts described by Sanz to disrupt 'tribal' marriages at the Drysdale River Mission, the Benedictine missionaries did not typically resist state requirements with respect to mixed-descent marriage.

\footnotetext{
116 Haebich 1988: 245, 261-62; Biskup 1973: 215-16; Choo 2001: 226-27; Zogbaum 2003: 122, 125, 126, 131. 117 Holland 2001: 292-301.

118 Haebich 1988: 349-50; Jacobs 1990: 260; Aboriginal Welfare: Initial Conference of Commonwealth and State Aboriginal Authorities, 1937: 11, National Library of Australia, nla.gov.au/nla.aus-vn118931 (accessed 28 August 2015). 119 Holland 2015: 206.

120 Copping to Catalan, 31 July 1923, ABCNN 05120; Catalan to Copping, 26 August 1923, ABCNN 01425; Catalan to Neville, 7 March 1928, ABCNN 01430; Bray to Alcade, 24 July 1934, ABCNN 05120; Catalan to Neville, 20 February 1935, ABCNN 01436; Neville to Catalan, 28 February 1935, ABCNN 05120; Neville, Circular 101, 16 July 1930, State Records Office of Western Australia (hereafter SROWA) Cons 993, 1930/0234; Catalan to Neville, 22 July 1930, SROWA Cons 993, 1930/0234.

121 Neville to Catalan, 3 November 1934, ABCNN 05120; Catalan to Neville, 7 November 1934, ABCNN 01436 .
} 
During Neville's term, New Norcia and Drysdale River priests performed 123 marriages, equating to approximately five marriages per year. ${ }^{122}$ This relatively small number of marriages belies the range and complexity of issues confronting the Benedictine missionaries with respect to marriage. New Norcia priests regarded compliance with correct religious procedure as paramount, and were unwilling to compromise even when their intransigence created significant tensions in their relationship with Neville and the Aborigines Department. Like the Mount Margaret Mission, the Benedictine missionaries acknowledged the negative impacts of 'tribal' marriages upon local Aboriginal populations, yet such concerns did not warrant their open defiance of state requirements. Instead, they attempted to redress the situation quietly, until the significant consequences of their decisions emerged after Neville's term. Finally, Catalan's cooperation with official requirements regarding mixed-descent marriage indicates a level of apathy regarding Neville's planned absorption of the Aboriginal population. That New Norcia's population was largely of mixed descent, effectively lessening the potential for unions that would challenge Neville's directive, might partially account for this attitude. ${ }^{123}$ However, Catalan's greater need for state acceptance of the mission's religious purpose, and especially to support his concerns regarding inter-faith marriage, outweighed his desire to make waves with the authorities on this particular issue of mixed marriage.

\section{Conclusion}

The complicated relationship between A.O. Neville and Abbot Catalan provides an illuminating snapshot of the challenges faced by mission organisations due to state interference. Most important, however, are the impacts of this complicated relationship upon the local Indigenous people, and the occasional Aboriginal voices emerging from the documents provide small, yet valuable, hints of their reactions to state and mission interference in their lives. At times, Benedictine missionaries were benevolent in their treatment of Aboriginal residents. However, other incidents demonstrated their almost callous disregard for the Aboriginal community's opinions and, most importantly, their future happiness and well-being. Underpinning each of the three themes is the Benedictine missionaries' sense of vulnerability during Neville's era. While Catalan may have over-exaggerated Neville's anti-mission stance as a specifically anti-Catholic position, the perceived threat to his missions' religious purpose heavily influenced the Abbot's relationship with Neville. Catalan was concerned by the direct impacts of Neville's interference in the lives of Aboriginal people, particularly when such interference diminished his own capacity to provide health care and protection to mission residents. To a significant extent, however, he was powerless to resist Neville's demands. Yet unlike other mission communities,

122 Marriage Register, Marriages Performed between 1915 and May 1940, ABCNN.

123 Catalan, Evidence from the Moseley Royal Commission, SROWA Cons 2922, Item 1: 19. 
Catalan did not appear concerned about the broader implications of Neville's decisions regarding the future of Western Australia's Aboriginal people, such as those associated with the policy of 'biological absorption'. Indeed, rather than the open opposition that had characterised Catalan's reaction to Neville's accommodation of mixed-faith marriages, the Abbot was visibly compliant with Neville's restrictions on mixed-descent marriages. In this respect, the heavily negotiated nature of the state-mission relationship becomes clearer as the Abbot carefully weighed Neville's demonstrated intransigence on issues of Aboriginal oversight and 'racial' mixing with his own responsibility to protect the mission's religious purpose. In such uncertain times, Catalan's struggle with Neville over the Benedictine missions' religious integrity was perhaps the only battle he could conceivably win.

\section{Acknowledgements}

I would like to acknowledge the support I received from the New Norcia Aboriginal Corporation, especially the generosity and kindness shown by former director Margaret Drayton.

Abbot John of the Benedictine Community of New Norcia kindly granted me permission to access the archives, and archivist Peter Hocking provided valuable and patient assistance.

\section{References}

\section{Archival sources}

Archives of the Benedictine Community of New Norcia (ABCNN)

01418, Correspondence from Catalan 1916

01420, Correspondence from Catalan 1918

01425, Correspondence from Catalan 1923

01430, Correspondence from Catalan 1929

01432, Correspondence from Catalan 1931

01433, Correspondence from Catalan 1932

01434, Correspondence from Catalan 1933

01436, Correspondence from Catalan 1935

01438, Correspondence from Catalan 1937

01442, Correspondence from Catalan 1940

05118, Correspondence concerning Aboriginals, Policy 
ABORIGINAL HISTORY VOL 422018

05119, Correspondence concerning Aboriginals, Policy

05120, Correspondence Relating to Aboriginals

Marriage Register of New Norcia

\section{State Records Office of Western Australia (SROWA)}

Consignment 993 1930/0234 - Marriage between Aboriginals or Half Caste Couples.

Consignment 2922 Item 1 - Royal Commission into the Condition and Treatment of Aborigines, Transcripts of Evidence 1934, AN 537.

\section{Legislation}

Aborigines Act 1905 (WA)

Aborigines Protection Act 1886 (WA)

Native Administration Act 1905-1936 (WA)

\section{Official reports}

Aboriginal Welfare: Initial Conference of Commonwealth and State Aboriginal Authorities held at Canberra, 21st to 23rd April, 1937, L.F. Johnston, Commonwealth Government Printer, Canberra. National Library of Australia (NLA), nla.gov.au/nla.aus-vn118931 (accessed 28 August 2015).

Western Australia, Royal Commission 1935, Report of the Royal Commission Appointed to Investigate, Report and Advise upon Matters in relation to the Condition and Treatment of Aborigines, 1935, Fred. Wm. Simpson, Government Printer, Perth. NLA, www.nla. gov.au/apps/doview/nla.aus-vn4739546-p.pdf (accessed 5 July 2015).

\section{Published sources}

Biskup, Peter 1973, Not Slaves Not Citizens: The Aboriginal Problem in Western Australia 1898-1954, University of Queensland Press, St Lucia.

Briscoe, Gordon 2003, 'The great health panic: Leprosy, Aborigines, Church and State in Western Australia, 1930-40', in Counting, Health and Identity: A History of Aboriginal Health and Demography in Western Australia and Queensland, 1900-1940, Gordon Briscoe (ed.), Aboriginal Studies Press, Canberra: 173-220.

Choo, Christine 1997, 'The role of the Catholic missionaries at Beagle Bay in the removal of Aboriginal children from their families in the Kimberley region from the 1890s', Aboriginal History 21: 14-29.

Choo, Christine 2001, Mission Girls Aboriginal Women on Catholic Missions in the Kimberley, Western Australia, 1900-1950, University of Western Australia Publishing, Perth. 
Comaroff, John L. 1997, 'Images of empire, contests of conscience: Models of colonial domination in South Africa', in Tensions of Empire: Colonial Cultures in a Bourgeois World, Frederick Cooper and Ann Laura Stoler (eds), University of California Press, Berkeley: 163-97. doi.org/10.1525/california/9780520205406.003.0005.

Durack, Mary 1969, The Rock and the Sand, Corgi Books, Ealing.

Ellinghaus, Katherine 2003, 'Absorbing the 'Aboriginal problem': Controlling interracial marriage in Australia in the 19th and early 20th centuries', Aboriginal History 27: 183-207.

Haebich, Anna 1988, For Their Own Good: Aborigines and Government in the Southwest of Western Australia, 1900-1940, University of Western Australia Press, Perth.

Haebich, Anna 2000, Broken Circles: Fragmenting Indigenous Families 1800-2000, Fremantle Arts Centre Press, North Fremantle.

Haebich, Anna and Ann Delroy 1999, The Stolen Generations: Separation of Aboriginal Children from their Families, Western Australian Museum, Perth.

Harris, John 1994, One Blood: 200 Years of Aboriginal Encounter with Christianity: A Story of Hope, Albatross Books Pty Ltd, Sutherland.

Haskins, Victoria 2003, "Could you see to the return of my daughter": Fathers and daughters under the New South Wales Aborigines Protection Board child removal policy', Australian Historical Studies 121: 107-21.

Holland, Alison 2001, 'Wives and mothers like ourselves? Exploring white women's intervention in the politics of race, 1920s to 1940s', Australian Historical Studies 117: 292-310. doi.org/10.1080/10314610108596166.

Holland, Alison 2015, Just Relations: The Story of Mary Bennett's Crusade for Aboriginal Rights, University of Western Australia Publishing, Perth.

Hutchison, David 1995, A Town Like No Other: The Living Tradition of New Norcia, Fremantle Arts Centre Press, South Fremantle.

Jacobs, Pat 1990, Mister Neville, Fremantle Arts Centre Press, Fremantle.

Jensz, Felicity 2010, 'Controlling marriages: Friedrich Hagenauer and the betrothal of Indigenous Western Australian women in colonial Victoria', Aboriginal History 34: 35-54.

Kinnane, Stephen 2003, Shadow Lines, Fremantle Arts Centre Press, Fremantle.

Loos, Noel 1991, 'From church to state: The Queensland Government take-over of Anglican missions in North Queensland', Aboriginal History 15: 73-85.

Massam, Katharine 2012, 'Cloistering the mission: Abbot Torres and changes at New Norcia 1901-1910', The Australasian Catholic Record 89: 13-25. 
Massam, Katharine 2015, 'Missionary women and work: Benedictine women at New Norcia claiming a religious vocation', Journal of Australian Studies 39: 44-53. doi.org/10.1080/ 14443058.2014.990400.

Mol, Hans 1970, 'Mixed marriages in Australia', Journal of Marriage and Family 32(2): 293-300. doi.org/10.2307/350137.

Mulcahy, Clement 1993, 'Catalan, Anselm Mary (1878-1959)', Australian Dictionary of Biography, National Centre of Biography, The Australian National University, adb. anu.edu.au/biography/catalan-anselm-mary-9711, published first in hardcopy 1993 (accessed 1 August 2018).

Neville, A.O. 1947, Australia's Coloured Minority, Currawong, Sydney.

O'Farrell, Patrick James 1969, The Catholic Church in Australia: A Short History, 1788-1967, Geoffrey Chapman, London.

Rooney, Bernard 2006, 'An evolving concept of mission: New Norcia 1846-2006', The Australasian Catholic Record 83: 209-319.

Tomlinson, Derrick 2008, 'Too White to Be Regarded as Aborigines', PhD thesis, University of Notre Dame Australia, Fremantle.

Zogbaum, Heidi 2003, 'Herbert Basedow and the removal of Aboriginal children of mixed descent from their families', Australian Historical Studies 121: 122-38. doi.org/ 10.1080/10314610308596240. 
This text is taken from Aboriginal History, Volume 42, 2018, edited by Ingereth Macfarlane, published 2018 by ANU Press, The Australian National University, Canberra, Australia.

doi.org/10.22459/AH.42.2018.05 